
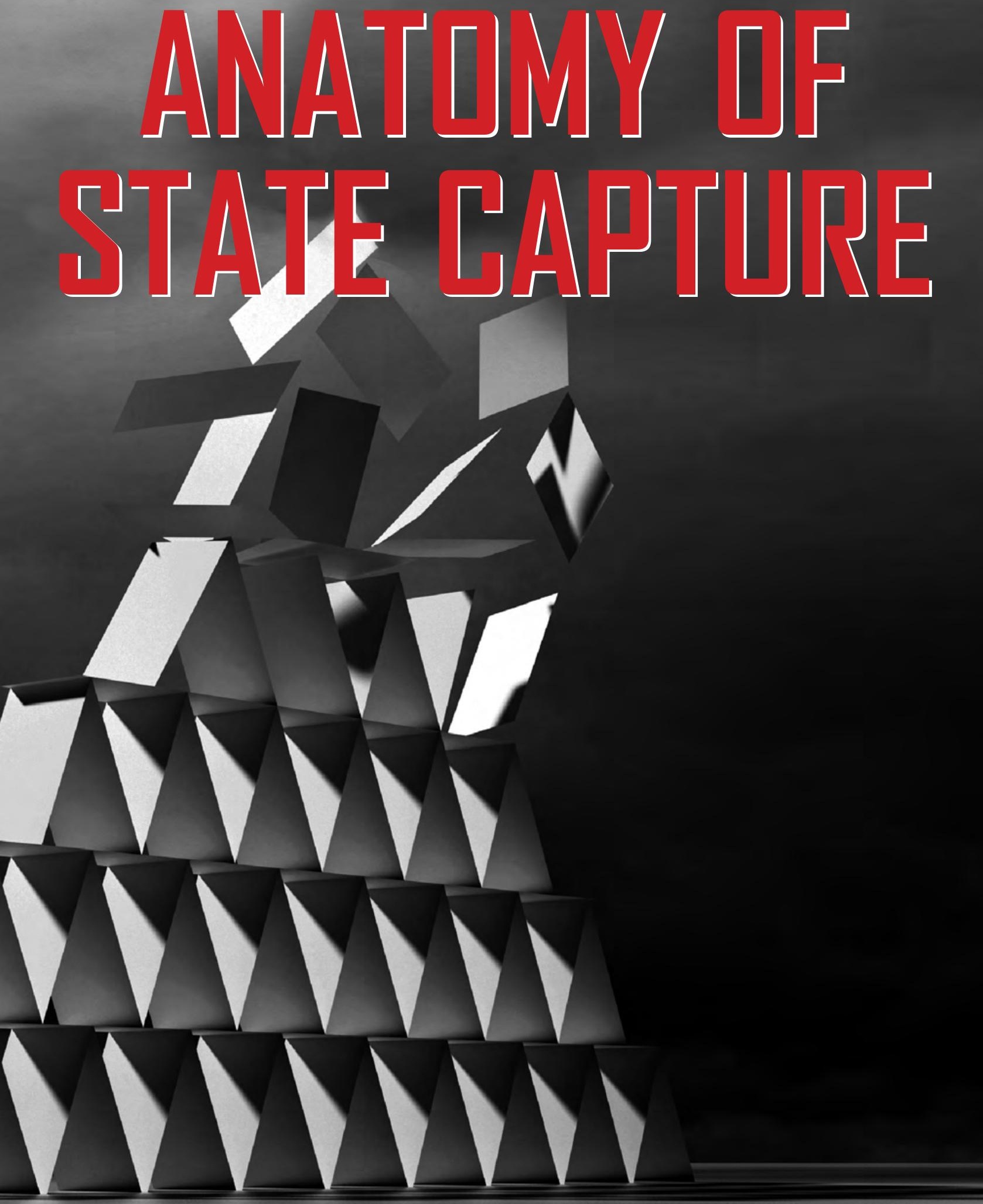

Nina Callaghan, Rabyn Foley and Mark Swilling (EDITuRS) 


\section{THE CASE OF STATE CAPTURE AT ESKOM}

Lauren Hermanus and Catrina Godinho

\subsection{INTRODUCTION AND CONTEXT}

When South Africa's former Public Protector, ${ }^{1}$ Thuli Madonsela, released the State of Capture report in November 2016, Eskom was the primary site of alleged wrongdoing. The State-Owned Company's (SOC) executives, procurement, and Board appeared to have facilitated public-private collaboration critical to the systematic looting of national resources. Events at South Africa's national public utility were said to proffer confirmation that the "relationship between the President and the Gupta family had evolved into 'state capture"' (Public Protector, 2016, p. 5).

That Eskom is pivotal to the state capture project is not surprising, given the scale and complexity that have characterised the organisation through its successive legal-institutional modulations. It is one of the largest power utilities in the world, operating in one of most energy intensive economy globally (Oyewo, Aghahosseini, Ram, Breyer \& Lohrmann, 2019). Its role in South Africa's economy has endowed its leaders with significant influence and power. Eskom and the associated private coal mining operations are inextricably linked to South Africa’s industrial and political development, and connected to powerful business interests. The market-dominant utility generates more than $90 \%$ of South Africa's electricity. It controls the entire national high voltage transmission grid, and distributes more than half of electricity directly to consumers. With annual revenues nearly three times that of Transnet and six times that of SAA, Eskom is by far the largest of South Africa's SOCs. For the 2018/19 financial year, its assets were valued in excess of R758bn, and its capital expenditure stood at R33.9bn (Eskom, 2019).

The concentration of capital, established resource flows, rich interdependencies, resilient public-private networks and an enduring lack of transparency have been

1 The Public Protector is one of six independent state institutions set up to support and defend democracy, subject only to South Africa's Constitution and the law, and report annually to Parliament (Republic of South Africa, 1996). In 2019, these line ministries and departments were merged again. 
critical to the state capture project at Eskom (Fine, 2010; Rafey \& Sovacool, 2011; Baker, 2019). As a SOC, Eskom sits at the centre of what has become popularly known as South Africa's minerals-energy complex (MEC). ${ }^{2}$ The MEC is a characterisation of a 'system of accumulation' comprising interdependent sectors, and public and private actors and interests, connected to and driven by energy-intensive extractive industries (Fine \& Rustomjee, 1996). What is significant about the MEC is that it shows how both positive and negative developments in the energy sector are not defined by a single actor, but arise out of actions across the public and private sectors. Close and murky dealings between Eskom, its suppliers and its large industrial consumers allowed for coherent and merged interests, habitually sheltered from public scrutiny. These longestablished relationships between government, Eskom and private companies are often viewed as critical to the national economy. However, the same relationships also have functioned as channels for grand corruption, that have escalated in the absence of checks and balances.

South Africa's parliament and judiciary have laid bare the mechanisms by which Eskom and related institutions were hollowed out, controlled by Gupta-Zuma-allied actors, and used to illegitimately transfer state resources to private companies at a staggering scale. The Eskom Inquiry ${ }^{3}$ and Zondo Commission ${ }^{4}$ have been instrumental in the iterative process of identifying and displacing the top cadres of state capture in the executive and governance structures of the utility and governing ministries. Unfortunately, remedies have come too late to arrest Eskom's financial and operational failure. The utility has been systematically gutted to the extent that it struggles to fulfil its mandate: to provide electricity in an efficient and sustainable manner to grow the economy and improve the quality of life of the people of South Africa.

This chapter traces the process of state capture at Eskom over time, with a focus on the period from 2010-2019. By constructing a temporal progression, it will explain how the state capture network first infiltrated and then parasitised the utility. It will be shown how veto positions were occupied, and policies and procedures were circumvented and later reformed, all contributing to the erosion of existing governance and accountability. The result was a gradual accumulation of control and power over the distribution of resources to a network of beneficiaries, as well as determining the shape of national electricity policy and the role of the power sector in the economy.

2 See, for example, the National Union of Metalworkers of South Africa's (NUMSA) press releases (NUMSA, 2010).

3 On 21 June 2017, the Portfolio Committee on Public Enterprises (the Committee) unanimously resolved to institute an oversight inquiry (Eskom Inquiry) into allegations of state capture at South African State-Owned Companies (SOCs) (Portfolio Committee on Public Enterprises, 2018). 


\subsection{SOUTH AFRICA'S LIGHTS GO OUT}

\subsubsection{Resistance to Eskom's Reform, Oversight and Accountability}

Eskom has always enjoyed a level of autonomy, shielded from external input by layers of secrecy. A 1998 Energy White Paper proposed a sweeping set of wholesale reforms to the sector (Department of Minerals and Energy, 1998). ${ }^{5}$ The White Paper's proposed reforms were aligned to international best practice, covering sector governance, structural reform, private investment and the introduction of renewable energy. However, resistance was resounding, from, for example, municipal governments and labour. Most significantly, resistance eminated from within national government and the utility itself (Van der Heijden, 2013). Regarding governance, between 1998 and 2019, the requirements for transparent sector planning and policymaking set out in the White Paper were circumvented. Over two decades, Eskom's operations remained opaque, particularly concerning power procurement, covering nuclear, coal and renewables (Baker, Burton, Godinho \& Trollip, 2015; Baker \& Phillips, 2018; Baker, 2019). Within this context, dysfunction, crisis-driven planning and grand corruption would become routine.

\subsubsection{The Lights Go Out}

Into the early 2000s, the ANC committed to extend energy access to the $64 \%$ of households formerly excluded by apartheid's racist infrastructure development (Baker, 2015). The country's electricity infrastructure that served the narrow needs and interests of the MEC and adjacent industries, as well as a white minority of residents, was reoriented around broad developmental objectives. However, planning failures would soon frustrate these ambitions. In the last quarter of 2007 , the country had experienced the first bouts of now familiar controlled rolling blackouts, termed 'loadshedding. By the end of the year, former President Thabo Mbeki apologised to the nation for failing to respond timeously to Eskom's preceding requests to approve new power generation investments (Van der Heijden, 2013). Demands on the country's limited resources were extensive.

The construction of massive coal-fired power plants, Medupi and Kusile (4800 MW in capacity each), soon forged ahead, requiring hundreds of billions of rands in international finance from the World Bank and other development finance institu-

5 Reforms included: the restructuring of generation and distribution, the introduction of private actors in energy generation, a transition to a greater share of renewable energy and for planning and policy functions to be formally shifted to what was then the Department of Minerals and Energy (DME)(Department of Minerals and Energy, 1998). Until 2009, the Department of Energy (DOE) had been the Department of Minerals and Energy, reporting to a single line ministry. 
tions (DFIs) (Rafey \& Sovacool, 2011). ${ }^{6}$ Through Broad-Based Black Economic Empowerment (BBBEE), Eskom's procurement spend on these projects and others was seen as one of few mechanisms available to transform the racial profile of industrial elites (Sovacool \& Saunders, 2014). The ostensive project of transformation unfolded within the MEC in ways that ultimately subverted this urgent national agenda to benefit only a narrow selection of politically powerful actors. As an example, the ANC's investment company, Chancellor House, was given a $25 \%$ equity stake in Hitachi Power Africa, which was then awarded boiler and turbine contracts for Medupi in 2007, in excess of R30 billion. Although illegal and shocking when it was exposed years later, the scale of this transaction would be dwarfed as corrupt deals escalated (Portfolio Committee on Public Enterprises, 2018).

\subsection{0-2014: FROM CORRUPTION TO STATE CAPTURE}

From 2010, there was a concerted effort to seize and reshape key institutions that were supposed to regulate Eskom, its appointments, operations and procurement, and ensure that it serves the country's developmental agenda. Historical networks of vested interests inside and outside the state were systematically expanded to include new actors seeking to establish and consolidate power. The first overt signs of this progression was to change the way the Ministry of Public Enterprises functioned in relation to Eskom.

\subsubsection{State Capture Cadres are Deployed to Relevant Ministries and Other Key Positions}

This reshaping or repurposing of Eskom commenced in earnest with the appointment of Malusi Gigaba as Minister of Public Enterprises by former President Zuma in November 2010. Enabled by Eskom's corporate governance protocol, this Ministry has enormous power, acting as the only representative of the company's sole shareholder (the South African sovereign). The Minister is required to oversee governance, appoint a Chief Executive, approve a Financial Director appointment, make nonexecutive Board appointments, and approve the Corporate Plan (which includes all planned financing). Gigaba had replaced Barbara Hogan, whose brief one-year tenure was terminated, allegedly for resisting Zuma's intimations at influencing SOC Board appointments (Portfolio Committee on Public Enterprises, 2018).

Former Eskom executives reported that there was an antagonistic relationship between the incumbent Eskom Board and the new Minister (Portfolio Committee on Public Enterprises, 2018). Gigaba's tenure commenced with an unprecedented interest in

6 Other generation expansion plans had included international deals to source power, for example, from Mozambique, as well as the Inga hydroelectricity project in the Democratic Republic of Congo (DRC) (Van der Heijden, 2013). 
Eskom's inner workings, policies, Board and significantly, major procurement underway at the time. In 2011, Gigaba quickly moved to supplant Eskom's Board, leaving only Bernie Fanaroff, and Boni Mehlomakulu (both appointed in 2010) in their positions. He appointed Zola Tsotsi to the position of Eskom Chairman. Although not clear at the time, Tsotsi appears to have been appointed to execute orders from outside, particularly those of the Gupta family, whose interests were allegedly taken as proxy for President Zuma's:

When I had the occasion to discuss something with him [Rajesh Gupta], and when I was not able to give it to him, he turned around and he said he must report me to Baba [President Jacob Zuma] ... The impression he gave me was that he had a very close relationship with Baba and that he could do anything. (Zola Tsotsi quoted in Portfolio Committee on Public Enterprises, 2018)

Tsotsi would be implicated in 2017, by several witnesses, in acts of corruption, as well as being characterised as a conduit for political interference in Eskom's operations and spending (Portfolio Committee on Public Enterprises, 2018). Gigaba and Tsotsi's Board comprised a host of individuals, many of whom were notably conflicted: Queendy Gungubele, Neo Lesela, Bejabulile Luthuli, Chwayita Mabude (removed by Brown in 2017 for Gupta links), Yasmin Masithela, Collins Matjila (linked to the Gupta family in the \#Guptaleaks emails), Mafika Mkwanazi (Transnet Chair), Phenyane Sedibe and Lily Zondo.

Eskom's Board plays an important role in approving major procurement, above a material threshold. Within the Board, the Board Tender Committee (BTC) is particularly instrumental in co-determining the procurement agenda, along with the more technical Executive Procurement Sub-Committee (EXCOPS). Gigaba and his new Board undermined procurement processes and expertise within the incumbent EXCOPS. Just months into the position, Gigaba refused to sign off on the award of a R4bn tender for the replacement of six steam generators at Koeberg Nuclear Power Plant (Portfolio Committee on Public Enterprises, 2018). The tender had already been through a technical review, ratified by the executive and approved by the Board. However, when it came to ratifying the decision, Gigaba refused. This was the first of a slew highly irregular procurement processes to take place under Gigaba and Tsotsi’s leadership.

\subsubsection{Setting Up a False Pro-transformation Smoke Screen to Cover Corruption}

Gigaba disingenuously framed his actions as the long overdue reversal of Eskom's historical role in the apartheid economy, of bolstering white business elites and serving white interests, broadly (Portfolio Committee on Public Enterprises, 2018; 
Baker, 2019). In contrast, Gigaba styled himself as the architect of a new black industrialist class, which, until his arrival, he saw Eskom as undermining through its procurement decisions. At the Eskom Inquiry, Ms Tsholofelo Molefe, then newly appointed Financial Director at Eskom, testified that Gigaba's Chief of Staff, Nhlanhla Msomi, requested that she take a meeting to address the dissatisfaction of black suppliers with Eskom's procurement processes:

[Mr Msomi] then indicated that there are [...] black suppliers that are complaining that Eskom is not providing them with contracts and they would like to meet and just lay their complaints [...] When I meet the supplier, it was Salim Essa and when I asked him what company he works for he, he did not divulge the company. (Tsholofelo Molefe quote in Portfolio Committee on Public Enterprises, 2018)

Far from promoting black business, Msomi, acting as Gigaba's emissary, opened the door for the notorious Gupta enforcer and intercessor, Salim Essa. Economic transformation provided the necessary cover for Essa to transplant consulting company, Regiments Capital, and later Trillian Capital, from Transnet's supply chain to Eskom's. Both companies would undertake corrupt deals, and function as agents for corrupt transactions and alleged money laundering, working in partnership with more established management consultancy, McKinsey \& Co, as well as other Gupta-linked companies. Direct payments to these companies would cost Eskom more than R1.5bn, excluding the irregular expenditure that they brokered. ${ }^{7}$ Gigaba also changed Eskom's rotation of auditors, retaining only one, SizweNtsalubaGobodo (SNG).

Even more boldly, Gigaba used his false transformation narrative to commandeer coal supply contracts in service of corrupt transactions and relationships. He insisted that Eskom's coal must be provided by miners with $50 \%+1$ (fifty percent plus one) black ownership by 2018/19 (Portfolio Committee on Public Enterprises, 2018). While this move appeared to be in line with the spirit of BBBEE, it was never formalised in any policy or clearly aligned to the legislative framework for transformation that exists in South Africa. There was no uniformity or transparency in the application of this rule. Instead, it appears that his vague proclamation was used as a mechanism to arbitrarily unseat incumbent suppliers - the so-called coal majors ${ }^{8}$ - and to empower

7 See the Report for Mr T.M.G Sexwale, Chairperson Trillian Capital Partners (Pty) Ltd on Allegations with regard to the Trillian Group of Companies and Related Matters" by Adv. Geoff Budlender, published on 29 June 2017; and the "Interim Report back to Eskom Holdings SOC Limited on an investigation of alleged irregularities in connection with the procurement of services from and payments to McKinsey and Company Africa (Pty) Ltd and Trillian Capital Partners (Pty) Ltd", published by Bowmans on 2 August 2017. the SOC had established relationships, for example, Anglo Coal, Glencore, South32 (previously BHP Billiton) and Exxaro. 
Gupta-linked, and not black-owned companies (Portfolio Committee on Public Enterprises, 2018). In fact, the Eskom Inquiry was presented with evidence that Exxaro (which, until recently, was majority black-owned), was squeezed out to make room for the Gupta-owned Tegeta (Portfolio Committee on Public Enterprises, 2018).

\subsection{STATE CAPTURE NETWORKS SEIZE CONTROL OF PROCUREMENT}

Evidence presented during the Eskom Inquiry revealed that the Gupta network had been attempting to secure coal contracts with Eskom since at least since 2010 (Portfolio Committee on Public Enterprises, 2018). These early attempts included proposals from Gupta associated Arctos Trading and Gupta-owned Idwala Coal. They were rebuffed due to their failure to meet various technical and environmental standards. The boundary walls were weakened from 2013 onwards, however. Eskom began to lose seasoned executives and senior staff, many of whom were suspended on unsubstantiated charges and refused fair disciplinary proceedings. Following credible threats to his safety, Brian Dames stepped down as Chief Executive Officer (CEO) in March 2014, replaced in an acting capacity by Board member, Collin Matjila. ${ }^{9}$

Matjila, formally of the National Energy Regulator of South Africa (NERSA), had already overseen some suspicious procurement as head of the BTC. Alarmingly, his appointment to $\mathrm{CEO}$, and by implication, his already problematic behaviour appears to have been commissioned by private sector non-Eskom and non-state actors. Evidence presented during the Eskom Inquiry revealed how Matjila's appointment was a coordinated effort on the part of members of the state capture network - perhaps the first overt instance of the Gupta-Zuma families' direct interference in the appointment of Eskom's executive (Portfolio Committee on Public Enterprises, 2018). The \#Guptaleaks emails contain alleged correspondence between Gupta broker, Saliem Essa, and the Gupta brothers, circulating and discussing Matjila's resume. The brothers allegedly then forwarded it to Mr D Zuma (former President Zuma's son) on 22 March 2014.

As head of the BTC, and then acting CEO, Matjila undermined existing governance norms and processes to funnel money into corrupt transactions. In this position, he rubber-stamped significant irregular procurement, including deals with the widely discredited Gupta media house, TNA Media. Eskom were to pay the company $\mathrm{R} 14 \mathrm{~m}$ for a total 12 corporate breakfasts. While acting as CEO, Matjila facilitated the

9 According to Mr Tsotsi, an earlier decision had been made that no Board member would take up the acting CEO position. Mr Tsotsi informed Minister Gigaba of a process to appoint Steve Lennon some time towards the end of 2013 or in early 2014. According to Mr Tsotsi, however, the ministerial approval was revoked in March 2014, shortly before Mr Dames' departure. 
ballooning of the TNA deal to R43m over a three-year term. He circumvented proper procurement procedures and also exceeded his mandated authority to get this deal approved, despite internal opposition from Eskom executives, Board members and legal counsel. This procurement is all the more problematic because it has since emerged that TNA Media was used as a mechanism to transmit money into Guptaconnected networks, including most notably, Oakbay Investments (Pty) Ltd, beneficiary of the illegal Optimum Coal Holdings transaction (Public Protector, 2016; Fundudzi Forensic Services, 2018; Portfolio Committee on Public Enterprises, 2018). Matjila facilitated other questionable procurement, including allegedly undermining an effort by Sal Laher (then Chief Information Officer) to save Eskom R1bn by internalising core IT functions. Instead, Eskom continued its relationship with the service provider, T-Systems, which is also connected to the Gupta network. In 2014, the Gupta-owned Tegeta submitted an official but unsolicited proposal to supply coal. With Eskom's personnel and processes significantly reconfigured, the Primary Energy Team accepted, despite Tegeta failing to meet coal quality, environmental and BBBEE requirements.

\subsubsection{The Lights Go Out Again in 2014}

By the end of 2014, Eskom's governance procedures were in chaos, and key positions were held by people since identified as part of the extended state capture network. Eskom's procurement funneled spending out of state coffers and circulating it through Eskom's suppliers to Gupta and Zuma-linked companies. Irregular and illegal processes ran in the shadows of Eskom's weakened institutions. As the focus of Eskom's leadership and ministry moved further and further away from Eskom's developmental purpose, load-shedding recommenced. Medupi and Kusile's construction was nowhere near scheduled completion, and spending was over budget and under scrutiny for irregularity. In this context, Matjila was replaced as CEO by Tshediso Matona. Mr Matona was tasked to bring order to the apparent chaos but he would be forced out by the same forces that ushered Matjila in (Portfolio Committee on Public Enterprises, 2018).

\subsection{MINISTER BROWN TAKES THE HELM AND THE PROJECT EXPANDS}

Having changed the character and role of the Minister of Public Enterprises' office, Gigaba was redeployed to Home Affairs. His successor, Lynn Brown, used and expanded the institutional space he created as an 'activist' shareholder. She began as Gigaba had, by replacing all but two non-executive members of the Board on 10 December 2014. Only Tsotsi and Mabude remained. What little institutional memory the Board had accumulated since Gigaba's overhaul just three and a half years 
earlier was again decimated. Six ${ }^{10}$ of Brown's eight new appointees had connections to the Gupta network and companies (Public Protector, 2016).

Soon after the Board reshuffle, in March 2015, Tsotsi oversaw an investigation into wrongdoing at Eskom, as well as the suspension of four executives, including Matona, Tsholofelo Molefe, Dan Marokane, and Matshela Koko. With load-shedding continuing and the SOC in serious financial trouble, these suspensions appeared unfounded and ill-advised (Portfolio Committee on Public Enterprises, 2018). In Tsotsi's testimony at the Eskom Inquiry, he indicated that his orders came via the Guptas, but went right to the top, to President Zuma himself (Capazorio, 2017). External private and political interests appeared intractably entangled with organisational function and governance. In this morass, the suspended executives had failed to comply with the new rules of the game, resulting in their departures. Koko was the only exception. He alone made it back from suspension, going on to be implicated in multiple irregular and illegal procurement scandals, connected to the Guptas and their political allies. ${ }^{11}$ Tsotsi's investigation closed, and the Board asked Dentons, the law firm that had conducted the investigation, to remove the names of any implicated individuals, including Koko, and companies in their final report. It was resolved to destroy all copies of the original draft. The final report then went to the Minister but was kept from the public and parliament.

\subsection{5-2019: CAPTURE INTENSIFIES WITH TWO NEW CAPTAINS}

On 17 April 2015, just before Koko would be reinstated as Group Executive for Technology and Commercial in July 2015, Minister Brown seconded Brian Molefe from Transnet and appointed him acting Chief Executive. In August 2015, Brown then seconded Anoj Singh, also from Transnet, and appointed him acting Chief Financial Officer (CFO). Molefe and Singh would be implicated in more corrupt and illegal deals as part of an unofficial network that extended into the Ministries of Public Enterprises, Energy, and Mineral Resources, the Presidency, private companies (including banks

10 The following information was reported to parliament and to the Zondo Commission. Dr Ngubane was a former Director of a company with a shareholding in Tegeta (Essa was also a shareholder). Mr Mark Pamensky has various Tegeta and Gupta-linked interests. Ms Devapushpum Viroshini Naidoo's spouse is a Director of Albatime, one of the companies that funded Tegeta's acquisition of Optimum Coal Holdings $(\mathrm{OCH})$, as well as an advisory to Minister of Mineral Resources, Mosebenzi Zwane. Ms Nazia Carrim is related by marriage to Essa. Mr Romeo Khumalo served on a Board with Essa. Ms Mariam Cassim is a former employee of the Gupta-linked Sahara Computers.

11 A report published by National Treasury found that "Mboweni, Koko, Nteta and Mabelane contravened the provisions of the Medium Term Mandate and section 57(c) of the PFMA in that they concluded or caused to be concluded, a CSA with an entity which was not 50\%+1 at the time of conclusion" (Fundudzi Forensic Services, 2018). 
and management consultancies), and various government departments. The origin and implementation of procurement decisions were unclear and not easily traceable. Official documentation from this time, reviewed through the Inquiry, often did not have requisite sign-off or was incomplete.

According to testimony before parliament and the Zondo Commission, Molefe and Singh were critical to the events that would eventually lead to the unravelling of the state capture web. Tegeta, now wedged in Eskom's supply chain, was undoubtedly the boldest and most costly achievement of the state capture project at Eskom. First, inflated contracts were signed with the Gupta-owned company, which displaced better quality and more affordable coal supply. ${ }^{12}$ Second, these contracts were expanded to increase Tegeta's winnings. Next came the most outrageous of all actions. Eskom facilitated and financed Tegeta's acquisition of Optimum Coal Mine (OCM) and Optimum Coal Holdings $(\mathrm{OCH})$ from Glencore (then majority shareholder from Glencore).

The story was astonishing. A public entity, Eskom, leaned on Glencore to force the sale of not only OCM, but also of its parent company, $\mathrm{OCH}$, to benefit another private company. In 2013, Glencore had invoked a hardship clause in OCM's coal supply agreement because costs exceeded the established price. This triggered a series of negotiations that eventually resulted in a new agreement drafted by Eskom. One of Molefe's first actions as acting Chief Executive, however, was to stop this process. What followed was an escalating exchange that would culminate in OCM instating a business rescue process on 31 July 2015. Shortly before, however, KPMG delivered a letter to Glencore stating that one of their clients, later revealed to be Guptalinked Oakbay Investments (Pty) Ltd, wanted to buy the mine. The business rescue practitioners testified to the pressure from Eskom executives to sell OCM, as well as $\mathrm{OCH}$, which had not originally been planned. Tegata, an Oakbay subsidiary, would put in an offer to purchase OCH. Tegeta's shareholders included Mabengela Investments (Pty) Ltd (owned by Duduzane Zuma) and Elgasolve (Pty) Ltd (owned by Salim Essa). In December, an offer to purchase was indeed accepted, but without funds to close the deal. Eskom executives orchestrated a range of payments to Tegeta and other Guptalinked companies, as well as an illegal guarantee in the amount of R1.68bn to Tegeta for an 'in principle' agreement to supply coal from a mine it did not yet own. All this was approved by Lynne Brown's Board. A public utility effectively bankrolled a private transaction with enormous risk to the country. The business rescue practitioners filed

12 In January 2015, Eskom entered into negotiations with Tegeta and on 10 March 2015, around the same time executives were suspended, a 5-year coal supply agreement (CSA) was signed, whereby Tegeta would supply 65000 tons of coal per month to Majuba Power Station at a rate of R277 per ton (a higher price than any other coal suppliers to Majuba and higher than Leeuwpan which is owned by Exxaro) effective 1 April 2015. 
a report with the Directorate of Priority Crime Investigation (DPCI) under Section 34 of the Prevention and Combating of Corrupt Activities Act, 2004 (Act 12 of 2004). The NPA took years to respond.

Molefe would resign soon after the State of Capture report was published. Following his resignation, Brian Molefe received an unheard-of R30m early pension payout, after just 18 months at Eskom. Contrary to the findings of the Inter-Ministerial Committee $^{13}$ established by former President Zuma in June 2017, the North Gauteng High Court ruled in January 2018 that the early retirement agreement was a "deliberate scheme devised by Eskom with the involvement of Mr Molefe". What's more, the Court found that Minister Brown and Eskom "acted irrationally in ignoring the damning allegations in the Public Protector's Report" that had precipitated Molefe's resignation. Eskom's payroll was already strained, as employees increased from 32000 to 47600 between 2003 and 2017.

Minister Brown reshuffled the Board again in June 2017, following the release of the State of Capture report (2016). The report shone a light on the role of a very compromised Board, enabling and legitimating irregular and illegal decisions and processes, particularly for the Gupta-linked Tegeta contract. Several members were patently conflicted when key resolutions were passed. In the fallout, there were several resignations and Chwayita Mabude was removed for alleged Gupta links. New Board members included Pulane Molokwane, Simphiwe Dingaan, Banothile Makhubela, and Sathiaseelan Gounden. With mounting political pressure, further changes were made, and an interim Board was appointed on 8 December 2019 by the Cabinet, presided over by President Zuma.

Zuma instated Zethembe Khoza as acting Chair. He would later also be implicated in the state capture project, allegedly informing Khulani Qoma, Eskom General Manager in the Office of the Chairperson, "Minister Brown is captured", at a meeting on 17 June 2017 (Portfolio Committee on Public Enterprises, 2018). The impact of this constant reshuffling was instability and a continued institutional erosion. Having replaced Minister Brown with former Finance Minister, Mr Pravin Gordhan, the newly inaugurated President Cyril Ramaphosa announced yet another new Board in January 2018. The new Board was also plagued by questions regarding its integrity and ability to steer Eskom towards a more stable and pro-development trajectory.

13 The Inter-Ministerial Committee comprised: Finance Minister Gigaba, Public Enterprises Minister Brown, Justice Minister Michael Masutha, and Energy Minister Mmamoloko Kubayi. This committee found that Eskom had mistakenly paid Mr Molefe his pension, but that "mistakes were made in good faith". 


\subsection{CONCLUSION: WHAT WAS LOST IN THE LOOTING}

The country's first Department-led Integrated Resource Plan (IRP) 2010-203014 included a plan, although contested, that appeared to herald an era of increasing transparency and accountability, in a sector so intertwined with toxic colonial and apartheid evolution of South Africa's state and economy. While officials updated the IRP in 2013, 2016 and 2018, the first ratified update was published in October 2019. This signals almost a decade without policy direction. In the interceding years, Eskom's ailing infrastructure continues to generate financial, ecological and social risks for South Africa's people. Additionally, in 2019, Medupi and Kusile had almost doubled projected costs, and have failed to solve the issue of nationwide loadshedding. While Eskom remains a public entity, it functioned as a porous membrane between state coffers and powerful private interests. Not only were institutions and resources captured, so too was the purpose and function of the electricity system

The full financial and opportunity costs of capture at Eskom is yet to be established. Although state capture networks rescinded, Eskom's internal issues continued. Evidence of this failure includes the R19bn in irregular expenditure exposed in the 2017/2018 financial report, increasing costs of primary energy and electricity, continued loadshedding and the risk of Eskom's debt to the national fiscus. The electricity system has been unjust in both process and outcome since its inception and state capture merely continued to entrench this. Structural reform now underway, unbundling Eskom into independent state-owned transmission, distribution and generation businesses, has been positioned as a remedy to the system that existed before state capture and allowed it to thrive. However, the existing crisis of accountability will demand more than a corporate governance fix. As the country transitions to a low-carbon economy, it will need to define and implement that 'more' to design an electricity system that is credibly developmental.

14 The first three national energy plans had been drafted by NERSA (Van der Heijden, 2013). This had drawn energy planning into a more public forum than had been the case during apartheid. 


\section{References}

Baker, L. (2015) 'Renewable energy in South Africa's minerals-energy complex: a "low carbon" transition?', Review of African Political Economy, 42(144):245-261. https://doi.org/10.1080/0305624 4.2014.953471

Baker, L. (2019) ‘Post-Apartheid Electricity Policy and the Emergence of South Africa's Renewable Energy Sector', in D. Arent, C. Arndt, M. Miller, F. Tarp \& O. Zinaman (eds.) The Political Economy of Clean Energy Transitions. Oxford: Oxford University Press, pp. 37-39.

Baker, L., Burton, J., Godinho, C. \& Trollip, H. (2015) 'The political economy of decarbonisation: Exploring the dynamics of South Africa's electricity sector', Energy Research Centre, University of Cape Town. Cape Town. [Online]. https://bit.ly/3lOgrRo

Baker, L. \& Phillips, J. (2018) 'Tensions in the transition: The politics of electricity distribution in South Africa, Environment and Planning C: Politics and Space, 37(1):177-196. https://doi. org/10.1177/2399654418778590

Capazorio, B. (2017) 'JZ told me to shed these top execs': Zola Tsotsi. State capture: Eskom chairman implicates No 1', Times Live. [Online].https://bit.ly/2VxSTpo

Department of Minerals and Energy (1998) White Paper on the Energy Policy of the Republic of South Africa, Department of Minerals and Energy. Pretoria.

Department of Minerals and Energy (2008) 'Nuclear Energy Policy for the Republic of South Africa', Department of Minerals and Energy. Pretoria. [Online]. https://bitly/ 3yB9dUA

Eskom (2019) Integrated Report 2018/19. Johannesburg.

Fine, B. (2010) 'Engaging the MEC: or a few of my views on a few things', Transformation: Critical Perspectives on Southern Africa, 71(1):26-49. https://doi.org/10.1353/ trn.0.0050

Fine, B. \& Rustomjee, Z. (1996) The Political Economy of South Africa: From Minerals- energy Complex To Industrialisation. New York: Routledge. https://doi.org/ 10.4324/9780429496004

Fundudzi Forensic Services (2018) 'Chapter III: Final Report: Forensic Investigation into various allegations at Eskom,' National Treasury. Pretoria.

Godinho, C. \& Hermanus, L. (2018) 'Reconceptualising State Capture - With a Case Study of South African Power Company Eskom', in State Capture and Its Aftermath: Building Responsiveness Through State Reform. Cape Town: Public Affairs Research Institute.

NUMSA (2010) NUMSA National Bargaining Conference Declaration, 29-31 March 2010. [Online].https://bit.ly/37rShE0

Oyewo, A.S., Aghahosseini, A., Ram, M., Breyer, C. \& Lohrmann, A. (2019) 'Pathway towards achieving 100\% renewable electricity by 2050 for South Africa', Solar Energy, 191:549-565. https://doi.org/10.1016/j. solener.2019.09.039

Portfolio Committee on Public Enterprises (2018) 'Final Report: Eskom Inquiry 28 Nov', Parliament of the Republic of South Africa. Cape Town. [Online]. https://bit.ly/ 3AjEZpB

Public Protector (2016) State of Capture. Pretoria. [Online].https://bit.ly/3xxbJtw (Accessed 1 September 2018).

Rafey, W. \& Sovacool, B.K. (2011) 'Competing discourses of energy development: The implications of the Medupi coal-fired power plant in South Africa, Global Environmental Change, 21(3):1141-1151.https://doi.org/ 10.1016/j.gloenvcha.2011.05.005

Republic of South Africa (1996) Constitution of the Republic of South Africa. Pretoria: Constitutional Assembly.

Sovacool, B.K. \& Saunders, H. (2014) 'Competing policy packages and the complexity of energy security', Energy, 67:641-651. https://doi.org/10.1016/j. energy.2014.01.039 
Van der Heijden, T. (2013) 'Why the Lights went Out: Reform in the South African Energy Sector', University of Cape Town Graduate School of Development Policy and Practice. Cape Town. [Online]. https://bit.ly/37oK2J5 (Accessed 6 November 2019). 


\section{APPENDIX}

\begin{tabular}{|c|c|c|c|c|}
\hline $\begin{array}{l}\text { Case Study } \\
\text { in State } \\
\text { Capture }\end{array}$ & Status & Summary Description & $\begin{array}{l}\text { Investigation } \\
\text { Body / } \\
\text { Source of } \\
\text { Evidence }\end{array}$ & $\begin{array}{l}\text { Government } \\
\text { Entity } \\
\text { Implicated }\end{array}$ \\
\hline \multicolumn{5}{|c|}{ Scandals Connected to Jacob Zuma, Guptas, Other Key Networks and ANC Politics } \\
\hline $\begin{array}{l}\text { The State } \\
\text { of Capture } \\
\text { report - } \\
\text { focuses } \\
\text { on Guptas' } \\
\text { relationship } \\
\text { with Jacob } \\
\text { Zuma and } \\
\text { their alleged } \\
\text { influence on } \\
\text { the affairs } \\
\text { of state }\end{array}$ & $\begin{array}{l}\text { First complaint } \\
\text { was received } \\
\text { in March } 2016 \\
\text { and the report } \\
\text { was released in } \\
\text { November } 2016 .\end{array}$ & $\begin{array}{l}\text { Investigation into complaints of alleged improper } \\
\text { and unethical conduct by the President and } \\
\text { other State Functionaries, relating to alleged } \\
\text { improper relationships and involvement of the } \\
\text { Gupta Family in the removal and appointment } \\
\text { of Ministers and Directors of State-Owned } \\
\text { Enterprises (SOEs), resulting in improper and } \\
\text { possibly corrupt award of State Contracts and } \\
\text { Benefits to the Gupta Family's Businesses. } \\
\text { The report details numerous allegations of } \\
\text { the Guptas' involvement in affairs of the state } \\
\text { and their irregular activities that enable rent } \\
\text { extraction. The findings were not conclusive } \\
\text { and the remedial action was to establish a } \\
\text { commission of inquiry into state capture (to } \\
\text { be appointed by the President, but with a } \\
\text { judge selected by the Chief Justice). Litigation } \\
\text { endeavoured to delay or prohibit the report's } \\
\text { release and implementation of remedial actions, } \\
\text { but failed, and the commission was established } \\
\text { in } 2018 \text {. }\end{array}$ & $\begin{array}{l}\text { - Public } \\
\text { Protector, } \\
\text { followed by } \\
\text { litigation }\end{array}$ & $\begin{array}{l}\text { - GCIS (The } \\
\text { New Age) } \\
\text { - Eskom } \\
\text { (Optimum) } \\
\text { - Transnet } \\
\text { (Regiments/ } \\
\text { Trillian) } \\
\text { - Denel } \\
\text { - SAA (The } \\
\text { New Age) } \\
\text { - SABC (The } \\
\text { New Age) } \\
\text { - Department of } \\
\text { Finance } \\
\text { - Transport } \\
\text { (SAA) } \\
\text { - Communica- } \\
\text { tions (SABC } \\
\text { \& GCIS) }\end{array}$ \\
\hline $\begin{array}{l}\text { Zondo } \\
\text { Commission }\end{array}$ & $\begin{array}{l}\text { Established } \\
\text { in 2018, with } \\
\text { anticipated } \\
\text { conclusion being } \\
\text { the end of } 2021 .\end{array}$ & $\begin{array}{l}\text { Formally titled the Judicial Commission of } \\
\text { Inquiry into Allegations of State Capture, } \\
\text { Corruption and Fraud in the Public Sector } \\
\text { including Organs of State, the Commission } \\
\text { was promulgated by then President Zuma in } \\
\text { response to the remedial actions as outlined in } \\
\text { the Public Protector's State of Capture report. } \\
\text { As of June } 2021 \text {, the Commission that started } \\
\text { in August } 2018 \text { has held more than } 418 \text { days } \\
\text { of hearings of over } 330 \text { testimonies (generating } \\
\text { over } 71000 \text { pages of transcript). The inquiry's } \\
\text { terms of reference were expansive and, as } \\
\text { such, the scope of investigations went beyond } \\
\text { merely looking into the Gupta-related cases, } \\
\text { covering other networks (e.g., Bosasa) as well } \\
\text { as other government institutions (e.g., role } \\
\text { of Parliament). }\end{array}$ & $\begin{array}{l}\text { - Zondo } \\
\text { Commission }\end{array}$ & $\begin{array}{l}\text { Various } \\
\text { work-streams } \\
\text { covering } \\
\text { inter alia: } \\
\text { - SOEs } \\
\text { (Eskom, } \\
\text { Transnet, } \\
\text { Denel, SAA) } \\
\text { - Free State } \\
\quad \text { Provincial } \\
\text { Government } \\
\text { - Bosasa } \\
\text { - SARS } \\
\text { - Law } \\
\text { enforcement } \\
\text { - State Security } \\
\text { Agency (SSA) } \\
\text { - The New Age } \\
\text { \& ANN7 } \\
\text { - Role of } \\
\text { Parliament } \\
\text { and ANC }\end{array}$ \\
\hline
\end{tabular}




\begin{tabular}{|c|c|c|c|c|}
\hline $\begin{array}{l}\text { Case Study } \\
\text { in State } \\
\text { Capture }\end{array}$ & Status & Summary Description & $\begin{array}{l}\text { Investigation } \\
\text { Body / } \\
\text { Source of } \\
\text { Evidence }\end{array}$ & $\begin{array}{l}\text { Government } \\
\text { Entity } \\
\text { Implicated }\end{array}$ \\
\hline \multicolumn{5}{|c|}{ Scandals Connected to Jacob Zuma, Guptas, Other Key Networks and ANC Politics } \\
\hline Bosasa & $\begin{array}{l}\text { Dating back to a } \\
2009 \text { SIU report. } \\
\text { Investigations and } \\
\text { various litigations } \\
\text { are ongoing. }\end{array}$ & $\begin{array}{l}\text { In 2019, former Bosasa C00, Anglo Agrizzi, } \\
\text { testified at the Zondo Commission, detailing } \\
\text { the acts and long history of corruption between } \\
\text { various Bosasa companies predominantly } \\
\text { owned by Gavin Watson, and numerous } \\
\text { government entities/departments. The } \\
\text { testimony of Agrizzi (and other former Bosasa } \\
\text { employees) corroborated the findings of a } \\
2009 \text { SIU investigation that alleged corruption } \\
\text { in several contracts Bosasa had with the } \\
\text { Department of Correctional Services. Criminal } \\
\text { court proceedings have been initiated based } \\
\text { on the } 2009 \text { SIU investigation, along with new } \\
\text { investigations initiated by SARS and other law } \\
\text { enforcement entities. }\end{array}$ & $\begin{array}{l}\text { - Special } \\
\text { Investi- } \\
\text { gation } \\
\text { Unit (SIU) } \\
\text { - Zondo } \\
\text { Commission }\end{array}$ & $\begin{array}{l}\text { - Department of } \\
\text { Correctional } \\
\text { Services } \\
\text { - Department of } \\
\text { Justice } \\
\text { - Department of } \\
\text { Home Affairs } \\
\text { - Department of } \\
\text { Transport } \\
\text { - Various SOEs } \\
\text { (e.g., SAPO, } \\
\text { ACSA) } \\
\text { - National } \\
\text { Prosecuting } \\
\text { Authority } \\
\text { (NPA) } \\
\text { - Members of } \\
\text { Parliament }\end{array}$ \\
\hline Arms Deal & $\begin{array}{l}\text { Various } \\
\text { investigations and } \\
\text { sources, dating } \\
\text { back to 1990s. } \\
\text { Most significant } \\
\text { source being } \\
\text { through Seriti } \\
\text { Commission. } \\
\text { Corruption case } \\
\text { against Zuma is } \\
\text { ongoing. }\end{array}$ & $\begin{array}{l}\text { Commission of Inquiry into allegations of fraud, } \\
\text { corruption, impropriety, or irregularity in the } \\
\text { Strategic Defence Procurement Packages } \\
\text { (SDPP). Various court cases related to } \\
\text { allegations of corruption against Jacob Zuma. } \\
\text { On Monday, } 24 \text { October 2011, the President } \\
\text { announced the Commission chaired by Judge } \\
\text { Seriti. The findings of the Commission were that } \\
\text { there was "no evidence" of corruption, but this } \\
\text { is seen by many to have been a whitewash. The } \\
\text { report was taken on review and set aside in } \\
\text { August 2019. The corruption case against Zuma } \\
\text { is ongoing before the courts. }\end{array}$ & $\begin{array}{l}\text { - Seriti } \\
\text { Commission } \\
\text { - Various } \\
\text { court cases }\end{array}$ & $\begin{array}{l}\text { Initially: } \\
\text { - South African } \\
\text { National } \\
\text { Defence } \\
\text { Force } \\
\text { - Members of } \\
\text { Parliament } \\
\text { Allegations also } \\
\text { involve: } \\
\text { - NPA } \\
\text { - SSA }\end{array}$ \\
\hline $\begin{array}{l}\text { Nkandla } \\
\text { Security } \\
\text { Upgrades }\end{array}$ & $\begin{array}{l}\text { Investigation } \\
\text { started in } \\
\text { November } 2012 . \\
\text { Report on } \\
\text { investigation } \\
\text { was released in } \\
\text { March } 2014 .\end{array}$ & $\begin{array}{l}\text { Report on security upgrades to President } \\
\text { Zuma's homestead in Nkandla. The investigation } \\
\text { found that the President unduly benefited from } \\
\text { the upgrades and as part of remedial actions } \\
\text { the President was required to pay back a portion } \\
\text { of the costs of the upgrades. Zuma instructed } \\
\text { that SAPS undertake their own investigation, } \\
\text { which sought to rationalise the expenses (fire- } \\
\text { pool report). Parliament accepted this alternative } \\
\text { report, but major court cases followed, } \\
\text { ultimately declaring that the Public Protector's } \\
\text { remedial actions are binding. President and } \\
\text { Parliament failed to uphold the Constitution. } \\
\text { President ordered to "pay back the money". }\end{array}$ & $\begin{array}{l}\text { - Public } \\
\text { Protector's } \\
\text { Secured } \\
\text { in Comfort } \\
\text { report, } \\
\text { followed by } \\
\text { litigation }\end{array}$ & $\begin{array}{l}\text { - Department of } \\
\text { Public Works } \\
\text { - South African } \\
\text { Police Service }\end{array}$ \\
\hline
\end{tabular}




\begin{tabular}{|c|c|c|c|c|}
\hline $\begin{array}{l}\text { Case Study } \\
\text { in State } \\
\text { Capture }\end{array}$ & Status & Summary Description & $\begin{array}{l}\text { Investigation } \\
\text { Body / } \\
\text { Source of } \\
\text { Evidence }\end{array}$ & $\begin{array}{l}\text { Government } \\
\text { Entity } \\
\text { Implicated }\end{array}$ \\
\hline \multicolumn{5}{|c|}{ Scandals Connected to Jacob Zuma, Guptas, Other Key Networks and ANC Politics } \\
\hline $\begin{array}{l}\text { Private } \\
\text { Aircraft } \\
\text { Landing at } \\
\text { Waterkloof } \\
\text { Airforce Base } \\
\text { and Gupta } \\
\text { Sun City } \\
\text { Wedding }\end{array}$ & May 2013. & $\begin{array}{l}\text { In 2013, justice, crime prevention, and } \\
\text { security cluster (JCPS) - a cabinet structure } \\
\text { composed of various ministries - undertook an } \\
\text { investigation into the Landing of a Commercial } \\
\text { aircraft at Air Force Base Waterkloof (report } \\
\text { titled the same). The investigation revealed that } \\
\text { the Guptas initially tried to organise a special } \\
\text { landing at OR Tambo International Airport, but } \\
\text { was turned down. They then approached the } \\
\text { Indian High Commission who re-designated the } \\
\text { wedding entourage as an official delegation to } \\
\text { secure a landing at the Waterkloof base. The } \\
\text { wedding held at Sun City was attended by a } \\
\text { number of high-profile ANC politicians and was } \\
\text { paid for in part by moneys looted from the Vrede } \\
\text { Dairy Farm project. }\end{array}$ & $\begin{array}{l}\text { - Report by } \\
\text { JPCS } \\
\text { - Zondo } \\
\text { Commission }\end{array}$ & $\begin{array}{l}\text { - Department of } \\
\text { International } \\
\text { Relations and } \\
\text { Cooperation } \\
\text { (DIRCO) } \\
\text { - Department of } \\
\text { Defence } \\
\text { - Department of } \\
\text { Transport }\end{array}$ \\
\hline $\begin{array}{l}\text { Free State } \\
\text { Provincial } \\
\text { Capture, } \\
\text { includes } \\
\text { Vrede Dairy } \\
\text { Farm and } \\
\text { Asbestos } \\
\text { Contracts }\end{array}$ & Ongoing. & $\begin{array}{l}\text { The Vrede Dairy Farm project was initiated } \\
\text { by the Free State Provincial Government as a } \\
\text { development project, however, in partnering with } \\
\text { a Gupta-linked company Estina, government } \\
\text { funds were looted. In 2018, the Public } \\
\text { Protector released a report on their } 2018 \\
\text { investigation, but it was taken on review and } \\
\text { set aside by the courts. The second part of the } \\
\text { investigation is yet to be finalised. The NPA } \\
\text { laid criminal charges against Gupta associates } \\
\text { and implicated government officials. Court } \\
\text { proceedings are ongoing. } \\
\text { Significant testimony and evidence have been } \\
\text { presented at the Zondo Commission regarding } \\
\text { the Vrede Farm case, as well as the asbestos } \\
\text { inspection project (criminal proceedings are also } \\
\text { underway). Both projects implicate high-profile } \\
\text { politicians and senior officials manipulating } \\
\text { government process. }\end{array}$ & $\begin{array}{l}\text { - } \text { Public } \\
\text { Protector } \\
\text { reports } \\
\text { - Zondo } \\
\text { Commission } \\
\text { - Various } \\
\text { court cases }\end{array}$ & $\begin{array}{l}\text { - Free State } \\
\text { Provincial } \\
\text { Government }\end{array}$ \\
\hline $\begin{array}{l}\text { Irregular } \\
\text { removal of } \\
\text { National } \\
\text { Director } \\
\text { of Public } \\
\text { Prosecutions } \\
\text { (NDPP), } \\
\text { Mxolisi } \\
\text { Nxasana }\end{array}$ & $\begin{array}{l}\text { Inquiry instituted } \\
\text { in February } 2015, \\
\text { but was cancelled } \\
\text { in May } 2015 . \\
\text { This triggers the } \\
\text { Constitutional Court } \\
\text { cases that followed. }\end{array}$ & $\begin{array}{l}\text { Inquiry into the fitness of Mxolisi Nxasana to } \\
\text { hold office as NDPP. The Inquiry was cancelled } \\
\text { after Zuma "agreed to let Nxasana resign". He } \\
\text { was paid R17m - the balance of his ten-year } \\
\text { contract. Court cases followed detailing the } \\
\text { abuse of the presidency powers by Zuma. } \\
\text { Ultimately, Nxasana was ordered to repay } \\
\text { R17m and Zuma's appointed replacement, } \\
\text { Shawn Abrahams, was ordered to vacate office. } \\
\text { Constitutional Court found Zuma's actions to } \\
\text { be an abuse of power and in breach of his } \\
\text { constitutional obligations. }\end{array}$ & $\begin{array}{l}\text { - Cassim } \\
\text { Inquiry into } \\
\text { fitness of } \\
\text { Mxolisi } \\
\text { Nxasana to } \\
\text { hold office } \\
\text { of NDPP } \\
\text { initiated } \\
\text { by Zuma, } \\
\text { followed by } \\
\text { litigation }\end{array}$ & $\begin{array}{l}\text { - National } \\
\text { Prosecution } \\
\text { Authority }\end{array}$ \\
\hline $\begin{array}{l}\text { Political } \\
\text { killings in } \\
\text { KZN }\end{array}$ & $\begin{array}{l}\text { Established in } \\
\text { October } 2016 . \text { The } \\
\text { report was released } \\
\text { in May } 2018 .\end{array}$ & $\begin{array}{l}\text { On } 28 \text { October 2016, the Premier of the } \\
\text { Province of KwaZulu-Natal established a } \\
\text { Commission of Enquiry into the Underlying } \\
\text { Causes of the Murder of Politicians in KwaZulu- } \\
\text { Natal (KZN). }\end{array}$ & $\begin{array}{l}\text { - Moerane } \\
\text { Commission } \\
\text { of Enquiry }\end{array}$ & $\begin{array}{l}\text { - KZN Provincial } \\
\text { Government } \\
\text { - KZN Local } \\
\text { Governments }\end{array}$ \\
\hline
\end{tabular}




\begin{tabular}{|c|c|c|c|c|}
\hline $\begin{array}{l}\text { Case Study } \\
\text { in State } \\
\text { Capture }\end{array}$ & Status & Summary Description & $\begin{array}{l}\text { Investigation } \\
\text { Body / } \\
\text { Source of } \\
\text { Evidence } \\
\end{array}$ & $\begin{array}{l}\text { Government } \\
\text { Entity } \\
\text { Implicated }\end{array}$ \\
\hline \multicolumn{5}{|c|}{ Scandals Connected to Jacob Zuma, Guptas, Other Key Networks and ANC Politics } \\
\hline \multicolumn{5}{|c|}{ State Capture of State-Owned Enterprises and Government Departments } \\
\hline $\begin{array}{l}\text { Interference } \\
\text { in operations } \\
\text { at the SABC }\end{array}$ & $\begin{array}{l}\text { The Ad Hoc } \\
\text { Committee was } \\
\text { established in } \\
\text { November } 2016 \\
\text { and final report } \\
\text { was tabled on } \\
24 \text { February } 2017 .\end{array}$ & $\begin{array}{l}\text { Parliamentary Ad Hoc Committee on the } \\
\text { SABC Board Inquiry into mismanagement and } \\
\text { interference in SABC operations. Findings } \\
\text { include evidence of Minister Faith Muthambi's } \\
\text { interference in the organisation and editorial } \\
\text { interference, in the firing of SABC } 8 \text { who } \\
\text { protested censorship of the national broadcaster } \\
\text { (on instruction from COO Hlaudi Motsoeneng). It } \\
\text { should be noted that the inquiry was preceded } \\
\text { by an investigation by the Public Protector. } \\
\text { Details are contained in the } 2014 \text { report titled } \\
\text { When Governance and Ethics Fail. }\end{array}$ & $\begin{array}{l}\text { - Parliamen- } \\
\text { tary Inquiry } \\
\text { - Preceded by } \\
\text { an investi- } \\
\text { gation by } \\
\text { the Public } \\
\text { Protector }\end{array}$ & $\begin{array}{l}\text { - SABC } \\
\text { (Department } \\
\text { of Communi- } \\
\text { cation) }\end{array}$ \\
\hline \multirow[t]{2}{*}{$\begin{array}{l}\text { Passenger } \\
\text { Rail Agency } \\
\text { of South } \\
\text { Africa } \\
\text { (PRASA) }\end{array}$} & $\begin{array}{l}\text { Complaints were } \\
\text { lodged in } 2012 \\
\text { and the report } \\
\text { was released in } \\
\text { August } 2015 .\end{array}$ & $\begin{array}{l}\text { Several cases of "mismanagement and } \\
\text { irregularities" regarding various contracts. } \\
\text { Lucky Montana was CEO at the time. One of } \\
\text { the remedial actions stipulated that National } \\
\text { Treasury was to investigate all PRASA contracts } \\
\text { from } 2012 \text { onwards with a value of R10 million } \\
\text { or more. National Treasury implemented the } \\
\text { remedial action which resulted in several } \\
\text { investigations, the details of which were leaked } \\
\text { to the public. }\end{array}$ & $\begin{array}{l}\text { - Public } \\
\text { Protector's } \\
\text { Derailed } \\
\text { report on } \\
\text { PRASA } \\
\text { - Numerous } \\
\text { investiga- } \\
\text { tions }\end{array}$ & $\begin{array}{l}\text { - PRASA } \\
\text { - Department of } \\
\text { Transport }\end{array}$ \\
\hline & $\begin{array}{l}\text { In June } 2017, \\
\text { Parliament directed } \\
4 \text { committees to } \\
\text { investigate state } \\
\text { capture. Committee } \\
\text { hearings were not } \\
\text { completed. }\end{array}$ & $\begin{array}{l}\text { In terms of the parliamentary directive, the } \\
\text { Portfolio Committee on Transport was requested } \\
\text { to establish an Inquiry into State Capture at } \\
\text { PRASA. However, the Portfolio Committee noted } \\
\text { that PRASA was not mentioned in the Public } \\
\text { Protector's State of Capture report and decided } \\
\text { they would focus on the various investigation } \\
\text { reports produced for National Treasury (as } \\
\text { recommended in Derailed report). }\end{array}$ & $\begin{array}{l}\text { - Portfolio } \\
\text { Committee } \\
\text { on Transport }\end{array}$ & $\begin{array}{l}\text { - PRASA } \\
\text { - Department of } \\
\text { Transport }\end{array}$ \\
\hline $\begin{array}{l}\text { Eskom } \\
\text { Inquiry into } \\
\text { State Capture }\end{array}$ & $\begin{array}{l}\text { In June } 2017 \text {, } \\
\text { Parliament directed } \\
4 \text { committees } \\
\text { to investigate } \\
\text { state capture. } \\
\text { Public Enterprises } \\
\text { Committee } \\
\text { report on Eskom } \\
\text { was released in } \\
\text { November } 2018 .\end{array}$ & $\begin{array}{l}\text { Extensive hearings were held by the Committee } \\
\text { detailing much of the evidence presented in } \\
\text { the Public Protector's report. The Committee } \\
\text { presented recommendations and compiled } \\
\text { a final report detailing their findings. These } \\
\text { included findings that Ministers Lynne Brown } \\
\text { and Malusi Gigaba were negligent and had to } \\
\text { be held accountable. Also recommended that } \\
\text { criminal investigations be undertaken against } \\
\text { the relevant Eskom executives. }\end{array}$ & $\begin{array}{l}\text { - Parliamen- } \\
\text { tary Inquiry }\end{array}$ & $\begin{array}{l}\text { - Eskom } \\
\text { - Department } \\
\text { of Public } \\
\text { Enterprises }\end{array}$ \\
\hline $\begin{array}{l}\text { Nugent } \\
\text { Commission } \\
\text { - SARS } \\
\text { Inquiry }\end{array}$ & $\begin{array}{l}\text { The Inquiry was } \\
\text { constituted on } \\
24 \text { May } 2018 \text { and } \\
\text { the final report } \\
\text { was released in } \\
\text { December } 2018 .\end{array}$ & $\begin{array}{l}\text { Commission of Inquiry into tax administration } \\
\text { and governance by South African Revenue } \\
\text { Service (SARS). Tom Moyane was fired based on } \\
\text { the interim report released in September } 2018 . \\
\text { The inquiry found that Moyane, with the help of } \\
\text { consultancy company Bain, had implemented } \\
\text { restructuring of the organisation, resulting in } \\
\text { gross mismanagement and erosion of SARS. } \\
\text { Moyane motivated the restructuring based on } \\
\text { the "rogue unit" narrative that has been the } \\
\text { subject of several other debunked investigations } \\
\text { and the subject of much litigation. }\end{array}$ & $\begin{array}{l}\text { - Judicial } \\
\text { Commission } \\
\text { of Inquiry } \\
\text { - Court cases } \\
\text { around the } \\
\text { "rogue unit" } \\
\text { narrative }\end{array}$ & $\begin{array}{l}\text { - SARS } \\
\text { (National } \\
\text { Treasury) }\end{array}$ \\
\hline
\end{tabular}




\begin{tabular}{|c|c|c|c|c|}
\hline $\begin{array}{l}\text { Case Study } \\
\text { in State } \\
\text { Capture }\end{array}$ & Status & Summary Description & $\begin{array}{l}\text { Investigation } \\
\text { Body / } \\
\text { Source of } \\
\text { Evidence }\end{array}$ & $\begin{array}{l}\text { Government } \\
\text { Entity } \\
\text { Implicated }\end{array}$ \\
\hline \multicolumn{5}{|c|}{ Scandals Connected to Jacob Zuma, Guptas, Other Key Networks and ANC Politics } \\
\hline \multicolumn{5}{|c|}{ State Capture of State-Owned Enterprises and Government Departments } \\
\hline $\begin{array}{l}\text { Commission } \\
\text { of Inquiry } \\
\text { into Public } \\
\text { Investment } \\
\text { Corporation } \\
\text { (PIC) }\end{array}$ & $\begin{array}{l}\text { In October } 2018 \text {, } \\
\text { the Commission } \\
\text { was constituted, } \\
\text { and the final report } \\
\text { was released in } \\
\text { March } 2020 .\end{array}$ & $\begin{array}{l}\text { Commission of Inquiry into allegations of } \\
\text { impropriety regarding Public Investment } \\
\text { Corporation (PIC). There were extensive hearings } \\
\text { on various 'dodgy' deals the PIC entered } \\
\text { into and details of political and executive } \\
\text { interference in the operations and decision- } \\
\text { making processes of the investment agency. }\end{array}$ & $\begin{array}{l}\text { - Judicial } \\
\text { Commission } \\
\text { of Inquiry }\end{array}$ & $\begin{array}{l}\text { - PIC (National } \\
\text { Treasury) }\end{array}$ \\
\hline $\begin{array}{l}\text { South African } \\
\text { Social } \\
\text { Security } \\
\text { Agency } \\
\text { (SASSA) }\end{array}$ & $\begin{array}{l}\text { Various } \\
\text { Constitutional Court } \\
\text { cases from } 2011 \\
\text { to } 2018 \text { resulted } \\
\text { in removal of CPS } \\
\text { as service provider } \\
\text { to SASSA. }\end{array}$ & $\begin{array}{l}\text { In 2014, South African Social Security Agency's } \\
\text { (SASSA) } 2012 \text { contract with CPS was found } \\
\text { to be irregular and invalid, however, due to the } \\
\text { importance of ensuring beneficiaries received } \\
\text { grants, CPS continued to be the service } \\
\text { providers until } 2018 \text {. Following a March } 2017 \\
\text { ruling, the Constitutional Court instituted a } \\
\text { Section } 38 \text { Inquiry into Minister Bathabile } \\
\text { Dlamini's personal liability for the narrowly } \\
\text { averted grant payment crisis. }\end{array}$ & $\begin{array}{l}\text { Primary } \\
\text { sources: } \\
\text { - AllPay court } \\
\text { case } \\
\text { - Black Sash } \\
\text { court case }\end{array}$ & - SASSA \\
\hline $\begin{array}{l}\text { South African } \\
\text { Airways (SAA) } \\
\text { and SAA } \\
\text { Technical }\end{array}$ & $\begin{array}{l}\text { Court case } \\
\text { to have Dudu } \\
\text { Myeni declared a } \\
\text { delinquent director } \\
\text { was launched } \\
\text { in } 2017 .\end{array}$ & $\begin{array}{l}\text { Court case was launched in } 2017 \text { by Outa and } \\
\text { the SAA Pilots' Association (SAAPA) to declare } \\
\text { Myeni a delinquent director in terms of the } \\
\text { Companies Act, based on her actions while she } \\
\text { was chairperson of the SAA Board. In 2020, the } \\
\text { High Court declared Myeni a delinquent director } \\
\text { for life. A significant amount of new evidence } \\
\text { also emerged through the Zondo Commission, } \\
\text { outlining how the operations at SAA were } \\
\text { undermined and how Myeni and others abused } \\
\text { their positions of authority. }\end{array}$ & $\begin{array}{l}\text { - Court } \\
\text { papers } \\
\text { - Zondo } \\
\text { Commission }\end{array}$ & $\begin{array}{l}\text { - SAA } \\
\text { - SAA Technical }\end{array}$ \\
\hline $\begin{array}{l}\text { Gupta Family } \\
\text { Naturalisation }\end{array}$ & $\begin{array}{l}\text { In June } 2017, \\
\text { Parliament directed } \\
4 \text { committees to } \\
\text { investigate state } \\
\text { capture. Final } \\
\text { report was tabled } \\
14 \text { March } 2019 .\end{array}$ & $\begin{array}{l}\text { Portfolio Committee on Home Affairs Inquiry into } \\
\text { the Gupta Family Naturalisation was established } \\
\text { in terms of the Parliamentary directive. Hearings } \\
\text { formally started on } 12 \text { September 2018. Final } \\
\text { report was tabled on } 14 \text { March 2019. Questions } \\
\text { were raised around contracts with Visa } \\
\text { Facilitation Services. This matter is ongoing as } \\
\text { of December } 2020 \text {. }\end{array}$ & $\begin{array}{l}\text { - Portfolio } \\
\text { Committee } \\
\text { on Home } \\
\text { Affairs }\end{array}$ & $\begin{array}{l}\text { - Department of } \\
\text { Home Affairs }\end{array}$ \\
\hline $\begin{array}{l}\text { Inquiry into } \\
\text { State Capture } \\
\text { related to } \\
\text { Gupta-owned } \\
\text { mines }\end{array}$ & $\begin{array}{l}\text { In June } 2017, \\
\text { Parliament directed } \\
4 \text { committees } \\
\text { to investigate } \\
\text { state capture. }\end{array}$ & $\begin{array}{l}\text { Though the Committee drafted a term of } \\
\text { reference for the Inquiry, the activities of holding } \\
\text { hearings and consolidating the evidence never } \\
\text { materialised beyond questions being put to then } \\
\text { Minister Zwane. }\end{array}$ & $\begin{array}{l}\text { - Portfolio } \\
\text { Committee } \\
\text { on Mineral } \\
\text { Resources }\end{array}$ & $\begin{array}{l}\text { - Department } \\
\text { of Mineral } \\
\text { Resources }\end{array}$ \\
\hline
\end{tabular}




\begin{tabular}{|c|c|c|c|c|}
\hline $\begin{array}{l}\text { Case Study } \\
\text { in State } \\
\text { Capture }\end{array}$ & Status & Summary Description & $\begin{array}{l}\text { Investigation } \\
\text { Body / } \\
\text { Source of } \\
\text { Evidence }\end{array}$ & $\begin{array}{l}\text { Government } \\
\text { Entity } \\
\text { Implicated }\end{array}$ \\
\hline \multicolumn{5}{|c|}{ Scandals Connected to Jacob Zuma, Guptas, Other Key Networks and ANC Politics } \\
\hline \multicolumn{5}{|c|}{ State Capture of State-Owned Enterprises and Government Departments } \\
\hline \multirow{3}{*}{$\begin{array}{l}\text { Various } \\
\text { investigations } \\
\text { relating to } \\
\text { State Capture } \\
\text { at Eskom }\end{array}$} & 2015 & $\begin{array}{l}\text { In 2015, Dentons produced an interim report } \\
\text { on their investigations into Status of Business } \\
\text { and Challenges at Eskom. Their investigation } \\
\text { was halted. }\end{array}$ & - Eskom & - Eskom \\
\hline & \multirow[t]{2}{*}{2017} & $\begin{array}{l}\text { In 2017, PricewaterhouseCoopers (PwC) was } \\
\text { appointed by National Treasury to investigate } \\
\text { Eskom's Coal Procurement Processes. Damning } \\
\text { findings were made in relation to Gupta-owned } \\
\text { Tegeta mine contracts and poor coal quality. }\end{array}$ & - Eskom & - Eskom \\
\hline & & $\begin{array}{l}\text { G9 was contracted by Eskom to investigate } \\
\text { the Trillian/McKinsey contracts. Interim report } \\
\text { presented to Board of Eskom in August } 2017 . \\
\text { The investigation remained incomplete, and } \\
\text { no report is available in the public domain. } \\
\text { Evidence from the investigation was presented } \\
\text { in the Parliamentary Inquiry into Eskom } \\
\text { State Capture. }\end{array}$ & $\begin{array}{l}\text { - National } \\
\text { Treasury }\end{array}$ & - Eskom \\
\hline $\begin{array}{l}\text { National } \\
\text { Treasury } \\
\text { Fundudzi } \\
\text { reports, } \\
\text { related to } \\
\text { Eskom and } \\
\text { Transnet (x3) }\end{array}$ & $\begin{array}{l}\text { Final reports } \\
\text { compiled in } \\
\text { November } 2018 \\
\text { and released to } \\
\text { the public shortly } \\
\text { thereafter. }\end{array}$ & $\begin{array}{l}\text { Investigations requested by National Treasury } \\
\text { of alleged corruption at Transnet and Eskom. } \\
\text { The three reports focused on Eskom (general), } \\
\text { the contracts related to Trillian/McKinsey and } \\
\text { Transnet Locomotives. }\end{array}$ & $\begin{array}{l}\text { - National } \\
\text { Treasury } \\
\text { Fundudzi }\end{array}$ & $\begin{array}{l}\text { - Eskom } \\
\text { - Transnet }\end{array}$ \\
\hline \multirow[t]{2}{*}{$\begin{array}{l}\text { Transnet } \\
\text { Locomotive } \\
\text { Contracts }\end{array}$} & \multirow[t]{2}{*}{$\begin{array}{l}\text { Investigations } \\
\text { commenced in } \\
\text { December } 2017 \\
\text { and reports on } \\
\text { findings submitted } \\
\text { during } 2018 .\end{array}$} & $\begin{array}{l}\text { Werksmans Attorneys was appointed in } \\
\text { December } 2017 \text { to undertake an investigation } \\
\text { into the } 1064 \text { Transnet Locomotives } \\
\text { procurement process, however, the investigation } \\
\text { was halted. No report in the public domain. }\end{array}$ & - Werksmans & - Transnet \\
\hline & & $\begin{array}{l}\text { Mncedisi Ndlovu \& Sedumedi (MNS) Attorneys } \\
\text { was then appointed to investigate } 1064 \\
\text { locomotives procurement process. The report } \\
\text { is not in the public domain, but media indicates } \\
\text { that recommendations mirror the Werksmans' } \\
\text { findings and recommends that Molefe face } \\
\text { criminal charges. }\end{array}$ & $\begin{array}{l}\text { - Mncedisi } \\
\text { Ndlovu \& } \\
\text { Sedumedi }\end{array}$ & - Transnet \\
\hline $\begin{array}{l}\text { Inquiry into } \\
\text { State Capture } \\
\text { at Transnet } \\
\text { and Denel }\end{array}$ & $\begin{array}{l}\text { In June } 2017, \\
\text { Parliament directed } \\
4 \text { committees to } \\
\text { investigate state } \\
\text { capture. Committee } \\
\text { hearings were not } \\
\text { completed. }\end{array}$ & $\begin{array}{l}\text { A detailed information booklet was prepared } \\
\text { in relation to Transnet, however, hearings were } \\
\text { not held before the end of term of Parliament. } \\
\text { Following National elections in 2019, it } \\
\text { was decided that outstanding Inquiries into } \\
\text { state capture be postponed indefinitely until } \\
\text { conclusion of the Zondo Commission. }\end{array}$ & $\begin{array}{l}\text { - Portfolio } \\
\text { Committee } \\
\text { on Public } \\
\text { Enterprises }\end{array}$ & $\begin{array}{l}\text { - Transnet } \\
\text { - Denel }\end{array}$ \\
\hline
\end{tabular}




\begin{tabular}{|c|c|c|c|c|}
\hline $\begin{array}{l}\text { Case Study } \\
\text { in State } \\
\text { Capture }\end{array}$ & Status & Summary Description & $\begin{array}{l}\text { Investigation } \\
\text { Body / } \\
\text { Source of } \\
\text { Evidence }\end{array}$ & $\begin{array}{l}\text { Government } \\
\text { Entity } \\
\text { Implicated }\end{array}$ \\
\hline \multicolumn{5}{|c|}{ Scandals Connected to Jacob Zuma, Guptas, Other Key Networks and ANC Politics } \\
\hline \multicolumn{5}{|c|}{ Law Enforcement and the Security Cluster } \\
\hline $\begin{array}{l}\text { Enquiry into } \\
\text { Jiba and } \\
\text { Mrwebi's } \\
\text { fitness to } \\
\text { hold office } \\
\text { at NPA }\end{array}$ & $\begin{array}{l}\text { Established in } \\
\text { November } 2018 . \\
\text { Report was issued } \\
\text { in April } 2019 .\end{array}$ & $\begin{array}{l}\text { Presidential Enquiry into the fitness to hold } \\
\text { office of suspended NPA senior advocates } \\
\text { Nomgcobo Jiba and Lawrence Mrwebi. NPA's } \\
\text { deputy head Jiba, and Mrwebi, the head of } \\
\text { the Specialised Commercial Crimes Unit, were } \\
\text { suspended in October } 2018 \text { by President Cyril } \\
\text { Ramaphosa. The Inquiry was headed by retired } \\
\text { Constitutional Court Justice Yvonne Mokgoro. } \\
\text { Jiba and Mrwebi were accused of improper } \\
\text { conduct in their handling of cases involving } \\
\text { former crime intelligence head Richard Mdluli, } \\
\text { as well as former KwaZulu-Natal Hawks boss } \\
\text { Johan Booysen. }\end{array}$ & $\begin{array}{c}\text { - Mokgoro } \\
\text { Enquiry }\end{array}$ & $\begin{array}{l}\text { - } \text { National } \\
\text { Prosecuting } \\
\text { Authority }\end{array}$ \\
\hline $\begin{array}{l}\text { High-Level } \\
\text { Review Panel } \\
\text { on the State } \\
\text { Security } \\
\text { Agency (SSA) }\end{array}$ & $\begin{array}{l}\text { Established in June } \\
2018 \text { and final } \\
\text { report was sent to } \\
\text { the President in } \\
\text { December } 2018 .\end{array}$ & $\begin{array}{l}\text { The High-Level Review Panel into the SSA } \\
\text { was established by President Ramaphosa in } \\
\text { June 2018. The key finding was a serious } \\
\text { politicisation and factionalisation of the } \\
\text { intelligence community over the past decade } \\
\text { or more. This resulted in "an almost complete } \\
\text { disregard for the Constitution, policy, legislation } \\
\text { and other prescripts, and [turned] our civilian } \\
\text { intelligence community into a private resource } \\
\text { to serve the political and personal interests of } \\
\text { particular individuals" (High-Level Review Panel } \\
\text { on the SSA, 2018, p.ii). }\end{array}$ & $\begin{array}{l}\text { - Review } \\
\text { Panel } \\
\text { established } \\
\text { by President } \\
\text { Ramaphosa }\end{array}$ & - SSA \\
\hline $\begin{array}{l}\text { Various court } \\
\text { cases against } \\
\text { persons } \\
\text { within law } \\
\text { enforcement }\end{array}$ & Ongoing. & $\begin{array}{l}\text { Though testimony and evidence have been } \\
\text { presented at the Zondo Commission, it is } \\
\text { understood that no definitive findings will be } \\
\text { made regarding the capture of law enforcement } \\
\text { under the Zuma administration. Since } 2012 \\
\text { onwards, there were several court cases } \\
\text { that were pursued against individuals in law } \\
\text { enforcement, all of which have been either } \\
\text { dismissed or withdrawn. Most noteworthy are } \\
\text { the cases involved, amongst others: Anwa } \\
\text { Dramat and Shadrack Sibiya of the Hawks } \\
\text { (and Robert McBride from Independent Police } \\
\text { Investigative Directorate [IPID]) for allegations } \\
\text { related to the "Zimbabwean rendition" matter; } \\
\text { Johan Booysen for alleged racketeering as part } \\
\text { of "Cato Manor hit squad"; and the various } \\
\text { senior officials accused of being part of the } \\
\text { "rogue" intelligence unit at SARS. Other court } \\
\text { cases that have provided significant evidence } \\
\text { indicating the capture of law enforcement relate } \\
\text { to the irregular appointed allies of the Shadow } \\
\text { State capture network or the irrational removal } \\
\text { of potential opponents holding senior positions } \\
\text { in law enforcement. Example is the irregular } \\
\text { removal of Mxolisi Nxasana as National Director } \\
\text { of Public Prosecutions (NDPP). }\end{array}$ & $\begin{array}{l}\text { - Various } \\
\text { court cases, } \\
\text { proceedings } \\
\text { in Parlia- } \\
\text { ment } \\
\text { - Zondo } \\
\text { Commission }\end{array}$ & $\begin{array}{l}\text { - NPA } \\
\text { - SAPS } \\
\text { - Hawks } \\
\text { - IPID }\end{array}$ \\
\hline
\end{tabular}




\begin{tabular}{|c|c|c|c|c|}
\hline $\begin{array}{l}\text { Case Study } \\
\text { in State } \\
\text { Capture }\end{array}$ & Status & Summary Description & $\begin{array}{l}\text { Investigation } \\
\text { Body / } \\
\text { Source of } \\
\text { Evidence }\end{array}$ & $\begin{array}{l}\text { Government } \\
\text { Entity } \\
\text { Implicated }\end{array}$ \\
\hline \multicolumn{5}{|c|}{ Scandals Connected to Jacob Zuma, Guptas, Other Key Networks and ANC Politics } \\
\hline \multicolumn{5}{|c|}{ Investigations concerning Private Sector } \\
\hline $\begin{array}{l}\text { Budlender } \\
\text { report on } \\
\text { Trillian }\end{array}$ & $\begin{array}{l}\text { Released in } \\
\text { June } 2017 .\end{array}$ & $\begin{array}{l}\text { Trillian Holdings Board appointed Geoff } \\
\text { Budlender SC to undertake investigations into } \\
\text { State Capture allegations at Trillian Capital. } \\
\text { Detailed accounts from whistle-blowers } \\
\text { highlighted how information was withheld by } \\
\text { senior management at Trillian. }\end{array}$ & - Trillion & - Eskom \\
\hline $\begin{array}{l}\text { Collapse of } \\
\text { VBS Mutual } \\
\text { Bank }\end{array}$ & $\begin{array}{l}\text { Investigation } \\
\text { launched in } \\
\text { April } 2018 \text { and } \\
\text { the report was } \\
\text { released in } \\
\text { October } 2018 .\end{array}$ & $\begin{array}{l}\text { Minister of Finance placed VBS under } \\
\text { curatorship with effect from } 11 \text { March 2018. In } \\
\text { April 2018, the Deputy Governor of the South } \\
\text { African Reserve Bank instituted an investigation } \\
\text { into VBS. The outcomes of the investigation } \\
\text { showed blatant fraud and corruption by senior } \\
\text { executives/Board and how they extracted } \\
\text { money from the bank. Municipal funds were } \\
\text { illegally deposited with VBS (senior ANC and } \\
\text { EFF politicians have been implicated). }\end{array}$ & $\begin{array}{l}\text { - SARB } \\
\text { investiga- } \\
\text { tion report } \\
\text { VBS Mutual } \\
\text { Bank - The } \\
\text { Great Bank } \\
\text { Heist }\end{array}$ & $\begin{array}{l}\text { - Several } \\
\text { Provincial and } \\
\text { Municipal } \\
\text { Officials } \\
\text { (Limpopo } \\
\text { Government) } \\
\text { - SOEs } \\
\text { (particularly } \\
\text { PRASA) }\end{array}$ \\
\hline $\begin{array}{l}\text { SA Institute } \\
\text { of Chartered } \\
\text { Accountants' } \\
\text { (SAICA) } \\
\text { investigation } \\
\text { into KPMG }\end{array}$ & $\begin{array}{l}\text { Final report was } \\
\text { handed to SAICA in } \\
\text { December } 2018 .\end{array}$ & $\begin{array}{l}\text { SA Institute of Chartered Accountants (SAICA) } \\
\text { established an Inquiry to investigate state } \\
\text { capture related allegations of misconduct of its } \\
\text { members who worked for KPMG. The Inquiry } \\
\text { chaired by advocate Dumisa Ntsebeza held } \\
\text { public hearings and handed its final report to } \\
\text { SAICA in December 2018. Indications are that } \\
\text { the final report will not be made public until all } \\
\text { investigations and disciplinary hearings have } \\
\text { been finalised. }\end{array}$ & - SAICA & - Guptas \\
\hline Bell Pottinger & $\begin{array}{l}2017 \text { investigation } \\
\text { by PRCA. }\end{array}$ & $\begin{array}{l}\text { In 2016, the Guptas appointed British PR } \\
\text { company, Bell Pottinger, who developed and } \\
\text { promoted a campaign that underpinned the RET } \\
\text { and WMC narratives. In 2017, there was an } \\
\text { independent law firm review by Herbert Smith } \\
\text { Freehills resulting in Bell Pottinger's expulsion } \\
\text { from the Public Relations and Communications } \\
\text { Association (PRCA). }\end{array}$ & $\begin{array}{l}\text { - PRCA } \\
\text { - GuptaLeaks } \\
\text { - Ongoing } \\
\text { research } \\
\text { on disinfor- } \\
\text { mation }\end{array}$ & - Guptas \\
\hline
\end{tabular}

